\title{
Correction to: Associations between prenatal Check for exposure to cadmium and lead with neural tube defect risks are modified by single-nucleotide polymorphisms of fetal MTHFR and SOD2: a case-control study
}

Mengyuan Liu ${ }^{1,2}$, Jinhui Yu ${ }^{1,2}$, Zaiming Su ${ }^{1,2}$, Ying Sun ${ }^{1,2}$, Yaqiong Liu ${ }^{1,2}$, Qing Xie ${ }^{1,2}$, Zhiwen Li ${ }^{1,2}$, Linlin Wang ${ }^{1,2}$, Jie Zhang ${ }^{1,2}$, Lei Jin ${ }^{1,2^{*}}$ and Aiguo Ren ${ }^{1,2,3^{*}}$

Correction to: Environmental Health 20, 66 (2021)

https://doi.org/10.1186/s12940-021-00752-9

Following the publication of the original article [1], the author reported an error in the affiliation list of Dr. Lei Jin and the address for the correspondence. Dr. Jins' affiliation should only be 1 and 2, and the address for both corresponding authors should be Institute of Reproductive and Child Health/Key Laboratory of Reproductive Health, National Health Commission of the People's Republic of China, Peking University, Beijing, China.

The affiliation number and the correspondence address are corrected above and the original article has been corrected.
Published online: 12 July 2021

\section{Reference}

1. Liu M, Yu J, Su Z, et al. Associations between prenatal exposure to cadmium and lead with neural tube defect risks are modified by single-nucleotide polymorphisms of fetal MTHFR and SOD2: a casecontrol study. Environ Health. 2021;20:66. https://doi.org/10.1186/ s12940-021-00752-9.

\section{Publisher's Note}

Springer Nature remains neutral with regard to jurisdictional claims in published maps and institutional affiliations.

\section{Author details}

'Institute of Reproductive and Child Health/Key Laboratory of Reproductive Health, National Health Commission of the People's Republic of China, Peking University, Beijing, China. ${ }^{2}$ Department of Epidemiology and Biostatistics, School of Public Health, Peking University, Beijing, China. ${ }^{3}$ Beijing Obstetrics and Gynecology Hospital, Capital Medical University, Beijing, China.

\footnotetext{
*Correspondence: jinlei@bjmu.edu.cn; renag@bjmu.edu.cn

${ }^{1}$ Institute of Reproductive and Child Health/Key Laboratory

of Reproductive Health, National Health Commission of the People's

Republic of China, Peking University, Beijing, China

Full list of author information is available at the end of the article
}

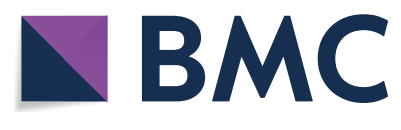

(c) The Author(s) 2021. Open Access This article is licensed under a Creative Commons Attribution 4.0 International License, which permits use, sharing, adaptation, distribution and reproduction in any medium or format, as long as you give appropriate credit to the original author(s) and the source, provide a link to the Creative Commons licence, and indicate if changes were made. The images or other third party material in this article are included in the article's Creative Commons licence, unless indicated otherwise in a credit line to the material. If material is not included in the article's Creative Commons licence and your intended use is not permitted by statutory regulation or exceeds the permitted use, you will need to obtain permission directly from the copyright holder. To view a copy of this licence, visit http://creativecommons.org/licenses/by/4.0/. The Creative Commons Public Domain Dedication waiver (http://creativeco mmons.org/publicdomain/zero/1.0/) applies to the data made available in this article, unless otherwise stated in a credit line to the data. 